OPEN ACCESS

Citation: José Esteban Jiménez, Jairo Hidalgo-Mora (2021) Matelea tarrazuana (Apocynaceae, Asclepiadoideae), a new critically endangered ocellate species from Central Pacific of Costa Rica. Webbia. Journal of Plant TaxonomyandGeography76(2):213-220. doi: 10.36253/jopt-10804

Received: April 19, 2021

Accepted: May 7, 2021

Published: September 7, 2021

Copyright:@2021 JoséEsteban Jiménez, Jairo Hidalgo-Mora. This is an open access, peer-reviewed article published by Firenze University Press (http:// www.fupress.com/webbia) and distributed under the terms of the Creative Commons Attribution License, which permits unrestricted use, distribution, and reproduction in any medium, provided the original author and source are credited.

Data Availability Statement: All relevant data are within the paper and its Supporting Information files.

Competing Interests: The Author(s) declare(s) no conflict of interest.

Editor: Lia Pignotti

ORCID

JEJ: https://orcid.org/0000-0002-81542156

JH-M: https://orcid.org/0000-00023502-6660

\section{Matelea tarrazuana (Apocynaceae, Asclepiadoideae), a new critically endangered ocellate species from Central Pacific of Costa Rica}

\author{
José Esteban JimÉneZ ${ }^{1,2, *}$, Jairo Hidalgo-Mora ${ }^{3}$ \\ ${ }^{1}$ Research Associate, Herbario Luis A. Fournier Origgi, Universidad de Costa Rica, Apdo. \\ 11501-2060, San José, Costa Rica \\ ${ }^{2}$ Gestión de Grupos Turísticos, Ingeniería en Ciencias Forestales y Vida Silvestre, Univer- \\ sidad Técnica Nacional, Apdo. 1902-4050, Alajuela, Costa Rica \\ ${ }^{3}$ Laboratorio de Ecología Funcional y Ecosistemas Tropicales (LEFET), Escuela de Cien- \\ cias Biológicas, Facultad de Ciencias Exactas y Naturales, Universidad Nacional, Here- \\ dia, Costa Rica \\ ${ }^{*}$ Corresponding author. E-mail: gaiadendron.jej@gmail.com
}

\begin{abstract}
Matelea tarrazuana, a new species endemic to Costa Rica, is described and illustrated. It is similar to M. pusilliflora, a vine from Yucatan Peninsula because of its green flowers with a reflective white spot in the apex at the apex of each lobe, but differs from that species by its longer pedicels, larger corolla lobes, staminal corona purple (vs. orange), gynostegium with the style apex purple (vs. green) and inhabiting premontane forests of Costa Rica. Data on its distribution and habitat, phenology, conservation status and taxonomy are included, as well as photographs of the living plant, and a key to identify the five related species in Mesoamerica.
\end{abstract}

Keywords: Endemic, floristics, Milkweed, premontane forest, Tarrazú.

\section{INTRODUCTION}

Matelea Aub. (Asclepiadoideae) is one of the largest genera within Apocynaceae comprising approximately 225 species worldwide (McDonnell 2014). It comprises herbaceous or woody neotropical vines (Stevens 2009, Cortez et al. 2018, Morales \& Stevens 2020), and is the largest genus in the New World subtribe Gonolobinae (G. Don.) Liede. (McDonnell 2014). It has been suggested that it has two centers of diversity: one includes southern Mexico-Guatemala, and the other in the north of South America (Spellman and Dwyer 1973, Villaseñor 2016).

Molecular studies have suggested that Matelea sensu Woodson (1941) is morphologically heterogeneous and not monophyletic (Krings et al. 2008; Morillo 2015). Here we follow the concept of the genus Matelea according to Stevens (2009). Traditionally, Matelea has a mixed indumentum of long, 
short and glandular hairs, the glandular always colored, extra-axillary inflorescences, rotate or campanulate corollas, staminal corona fused to the base of the corolla or the gynostegium, and horizontal or subhorizontal pollinia laterally excavated and sterile near the union with the caudicle (Stevens 2009).

Matelea has been studied twice recently in Costa Rica. Stevens (2009) suggest that the genus has 13 species, whereas Morales \& Stevens (2020) recognized 15 species. Because of this, it was unexpected to find a new species of this group. This taxon is unusual and conspicuously different in floral morphology from the other related species of Matelea in Mesoamerica, and belongs to a the "ocellate complex" (Krings 2012) characterized by its small-flowered species held together primarily by having a bright white reflective ocellus at the tip of each corolla lobe. Stevens and Arbelaez (2014) discusses the rarity of this group, and this new species reinforces the discussion and make the discovery more expected.

\section{MATERIALS AND METHODS}

The study area is located in the Zona de los Santos region (Tarrazú canton) in the Central Pacific of Costa Rica. The material was processed and incorporated into CR and USJ. The acronyms of herbaria mentioned in this work follow Thiers (2021). The description and illustration were based on live and dried material. Stevens (2009) and Cortez et al. (2018) were followed for the morphological terminology. Ecological life zone is described according to Holdridge et al. (1971). The assessments of the conservation status were made based on the guidelines of the International Union for Conservation of Nature (IUCN 2001), using parameters such as number of locations, extent of occurrence (criterion B1) and area of occupancy (criterion B2). Map was made using Photoshop.

\section{TAXONOMIC TREATMENT}

Matelea tarrazuana J.E.Jiménez \& J.E.Hidalgo-Mora, sp. nov. (Figures 1, 2).

Type: Costa Rica: San José, Tarrazú, San Lorenzo, San Joaquín, bosque a la par del río San Joaquín a 50 $\mathrm{m}$ aguas arriba del puente que lo atraviesa. Este río se convierte en el Río Naranjillo pocos metros aguas abajo cuando se une con la quebrada Pirranga, bosque primario intervenido, $1200-1300 \mathrm{~m}, 9^{\circ} 34^{\prime} 52.86^{\prime \prime} \mathrm{N}$, 8358'48.90" W, 28 Mar. 2020 (fl.), J.E. Jiménez \& J. Hidalgo-Mora 5058 (holotype: USJ!, isotype: CR!).

\section{Diagnosis}

Similar to Matelea pusilliflora L.O. Williams in having leaves ovate with the base slightly cordate or truncate, inflorescences racemose and congested and flowers green with a reflective white spot in the apex of each lobe, but differs from that species by its pedicels $0.4-0.6$ $\mathrm{cm}$ long (vs. $0.1-0.2 \mathrm{~cm}$ long), corolla lobes as long as wide, $0.4-0.5 \mathrm{~cm}$ long (vs. wider than long, $0.2-0.3 \mathrm{~cm}$ long), staminal corona purple (vs. orange), and gynostegium with the style apex and stigma purple (vs. green).

\section{Description}

Twining herbaceous vines, latex colorless. Stems cylindrical, slightly suberose and glabrescent with age, young branchlets puberulent to sericeous with translucent trichomes less than $0.1 \mathrm{~cm}$ long, old branchelets and main stems glabrous to puberulent. Leaves oppositedecussate in orthotropic stems and opposite-distichous in plagiotropic stems, increasing progressively in size in the plagiotropic stems from the proximal to distal nodes, yellow when withered; petioles $0.8-1 \mathrm{~cm}$ long, puberulent with translucent trichomes less than $0.1 \mathrm{~cm}$ long; leaf blades $2.5-6.5 \times 1.2-3.5 \mathrm{~cm}$, ovate, the apex acuminate to long-acuminate, the base cordate to slightly truncate, with a sinus of $0-0.5 \mathrm{~cm}$, leaves scarcely puberulent on adaxial side, with few trichomes less than $0.1 \mathrm{~cm}$ long and sparse to densely puberulent on the midveins and secondary veins abaxially; brochidodromous venation, with 4-6 pair of secondary veins; colleters at the base of the midrib on the adaxial side, 4-6, ca. $1 \mathrm{~mm}$ long. Inflorescences extra-axillary, one per node, condensedracemiform, $0.1-0.7 \mathrm{~cm}$ long, with straight disperse trichomes less than $0.1 \mathrm{~cm}$ long; peduncles $0.3-0.4 \mathrm{~cm}$ long; pedicels $0.4-0.6 \mathrm{~cm}$ long; bracts lanceolate, $0.2-0.3$ $\times$ ca. $0.1 \mathrm{~cm}$, margin ciliate with trichomes less than 0.1 $\mathrm{cm}$. Calyx lobes ovate-lanceolate, $0.4-0.5 \times 0.1-0.3 \mathrm{~cm}$, erect, puberulous. Corolla rotate, green to brownish green, with inconspicuous reticulate light green venation, with a bright white spot at the tip of each lobe, glabrous, tube $0.2 \mathrm{~cm}$ long, lobes ovate to nearly orbicular, flat and patent, $0.4-0.5 \times 0.4-0.5 \mathrm{~cm}$, apex obliquely acuminate to obtuse; staminal corona rounded-pentagonal surrounding gynostegium, purple to dark-purple, fleshy, with five semicircular wings folded in front of each anther. Gynostegium with a cylindrical stipe 0.1$0.2 \mathrm{~cm}$ tall covering by the corona, pentagonal, style apex rounded-pentagonal, convex in natural form, 10-15 $\mathrm{mm}$ wide, with a gray margin. Pollinaria ca. $15 \times 12-10$ $\mathrm{mm}$, corpuscle brown, slightly clavate; lamellar claudicle 10-12 mm long, pollinia oblong, ca. $10 \times 03-05 \mathrm{~mm}$, laterally excavated, oriented towards the posterior part of the anther. Follicles and seeds unknown. 


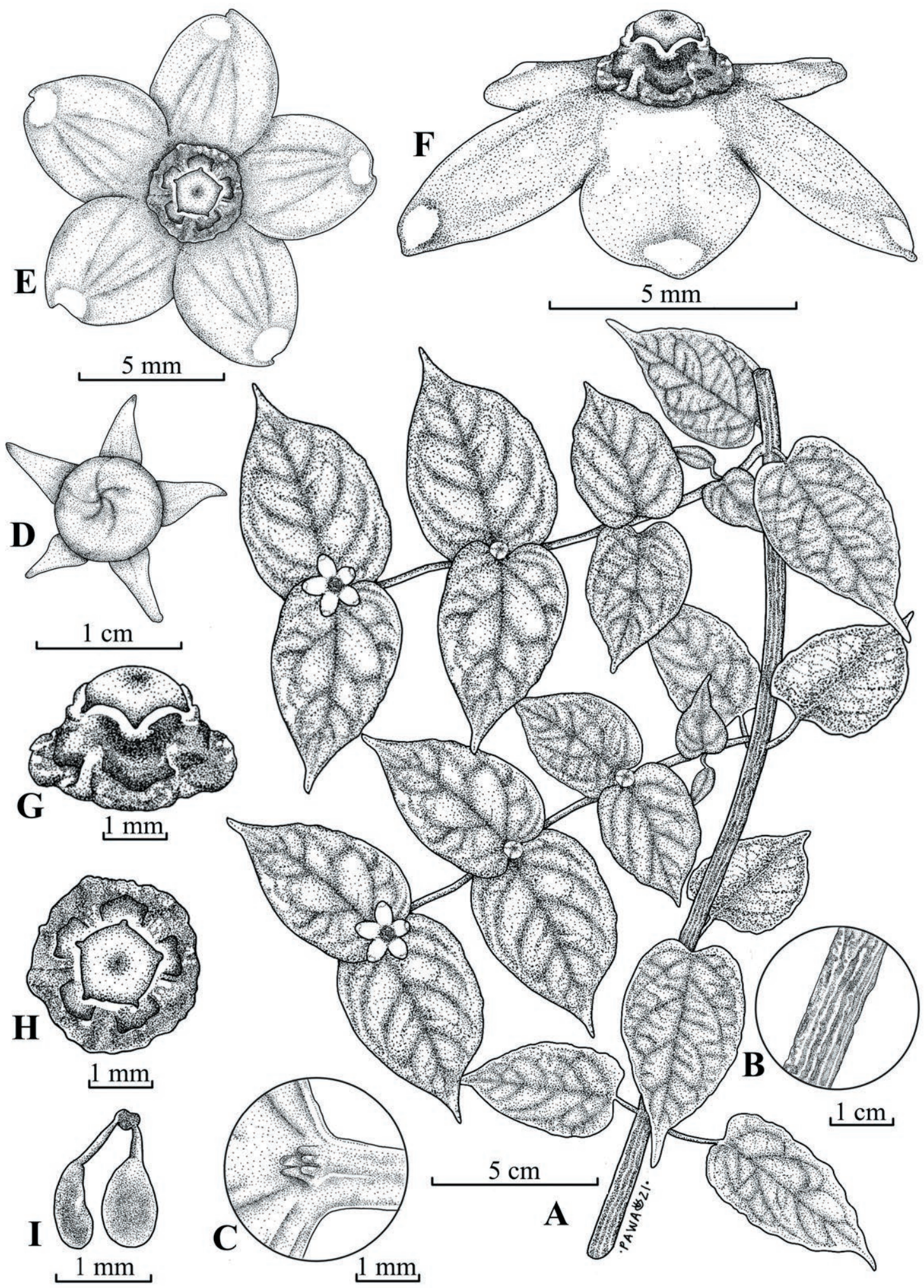

Figure 1. Matelea tarrazuana. A. Flowering branch. Notice orthotropic stem with an opposite-decussate phyllotaxy and plagiotropic stems with an opposite-distichous phyllotaxy. B. Detail of a stem segment. C. Colleters. D. Flower bud. E. Flower in frontal view. F. Flower in lateral view. G. Staminal corona and gynostemium in lateral view. H. Staminal corona and gynostegium in frontal view. I. Pollinarium. Illustration based on live photographs of the type specimen Jiménez \& Hidalgo-Mora 5058 (USJ). 

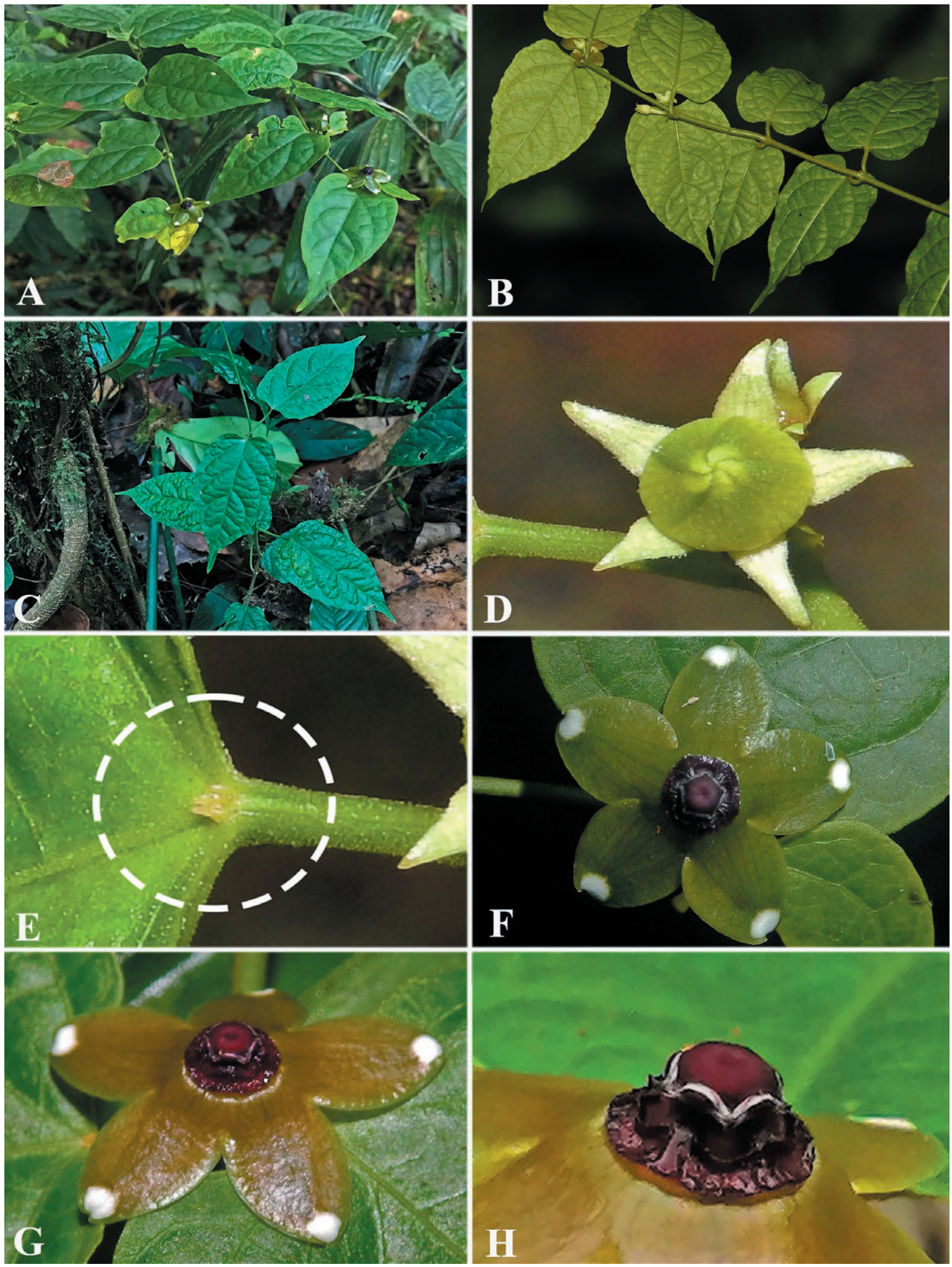

Figure 2. Matelea tarrazuana. A. Plagiotropic stems with an opposite-distichous phyllotaxy, adaxial side of leaves and flowers. B. Abaxial view of the leaves. C. Orthotropic stem with an opposite-decussate phyllotaxy. D. Flower bud with the calyx patent. E. Colleters on the base of the leaf blade. F. Green flower in frontal view. G. Brownish-green flower in lateral view. H. Detail of the staminal corona and gynostegium. Photographs based on type specimen Jiménez \& Hidalgo-Mora 5058 (USJ). 


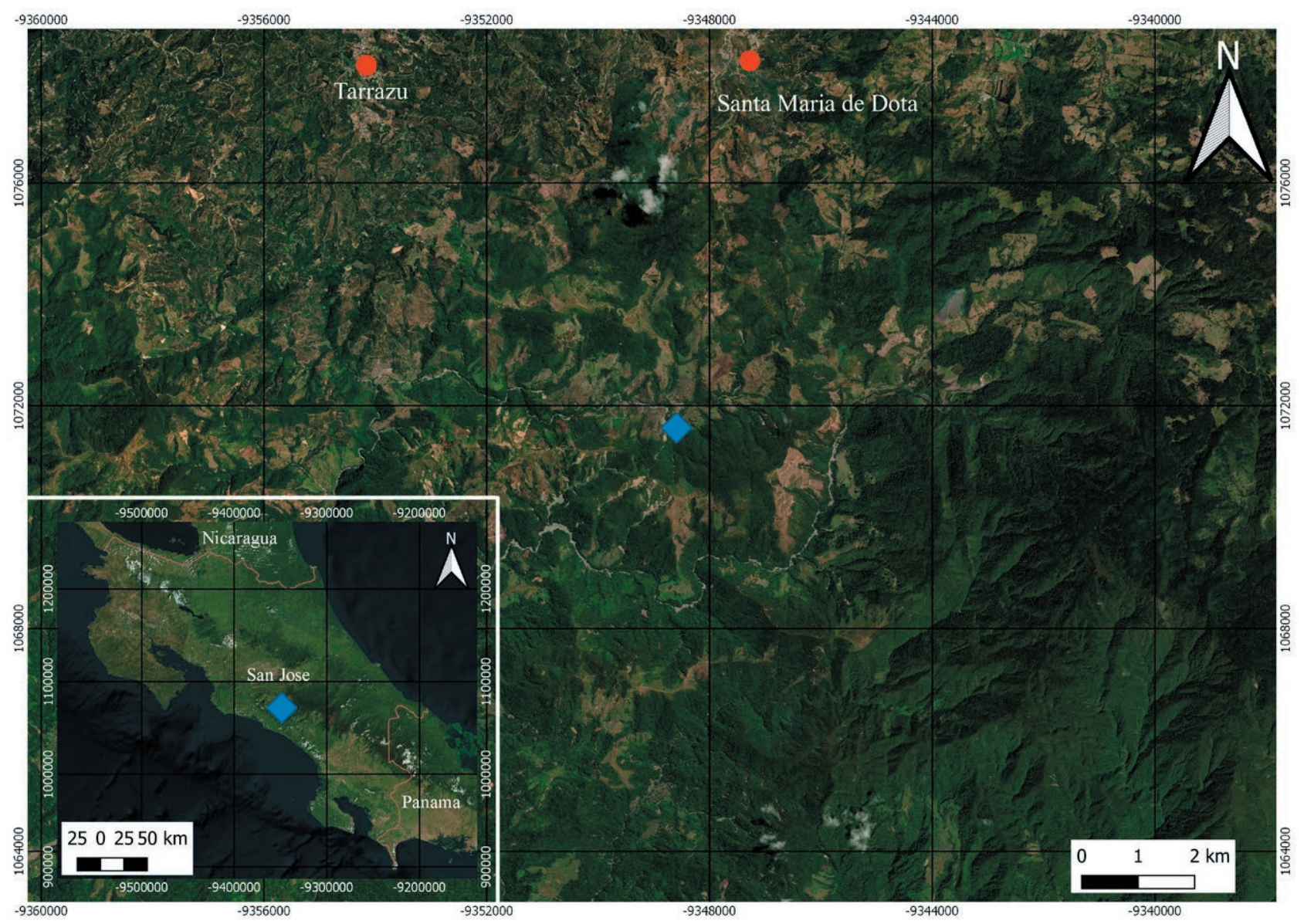

Figure 3. Distribution of Matelea tarrazuana J.E. Jiménez \& J.E. Hidalgo-Mora.

\section{Etymology}

This species is named after Tarrazú, locality of the type specimen.

\section{Distribution and habitat}

Matelea tarrazuana is endemic to Costa Rica. It is known only from the type locality, in primary and secondary forest in San Joaquín de Tarrazú, Zona de los Santos region, San José province, at $1249 \mathrm{~m}$ in a premontane rain forest (Figure 3).

\section{Phenology}

Flowering has been recorded in March during dry season, and November during rainy season. It was also observed in bloom during April, May, and July but no vouchers were prepared. No fruits were seen.

\section{Conservation Status}

Matelea tarrazuana is not protected in any protected state area or private reserve in Costa Rica The two specimens in herbaria and the single known population severely affected by unsustainable agricultural and livestock activities suggest that this species is rare. Despite to has a restricted natural distribution, the Data is Deficient (DD).

\section{Remarks}

Matelea tarrazuana is easily to recognize because of the reflective white spot in the apex of each corolla lobe, a diagnostic characteristic that share with $M$. corniculata, M. emmartinezii, M. pusilliflora, and M. ocellata in Mesoamerica. In Costa Rica, only M. corniculata and $M$. ocellata are reported, but in different ecosystems. Matelea corniculata grows in a tropical moist forest Sarapiquí, Heredia (La Selva Biological station), whereas M. ocellata has been found in tropical dry forest Santa Elena peninsula (Santa Rosa national park). Matelea tarrazuana can be separated from $M$. pusilliflora, by its longer pedicels (0.4-0.6 vs. $0.1-0.2 \mathrm{~cm})$, corolla lobes as long as wide, $0.4-0.5 \mathrm{~cm}$ long (vs. wider than long, $0.2-0.3 \mathrm{~cm}$ long), a purple staminal corona (vs. orange), and gynostegium 

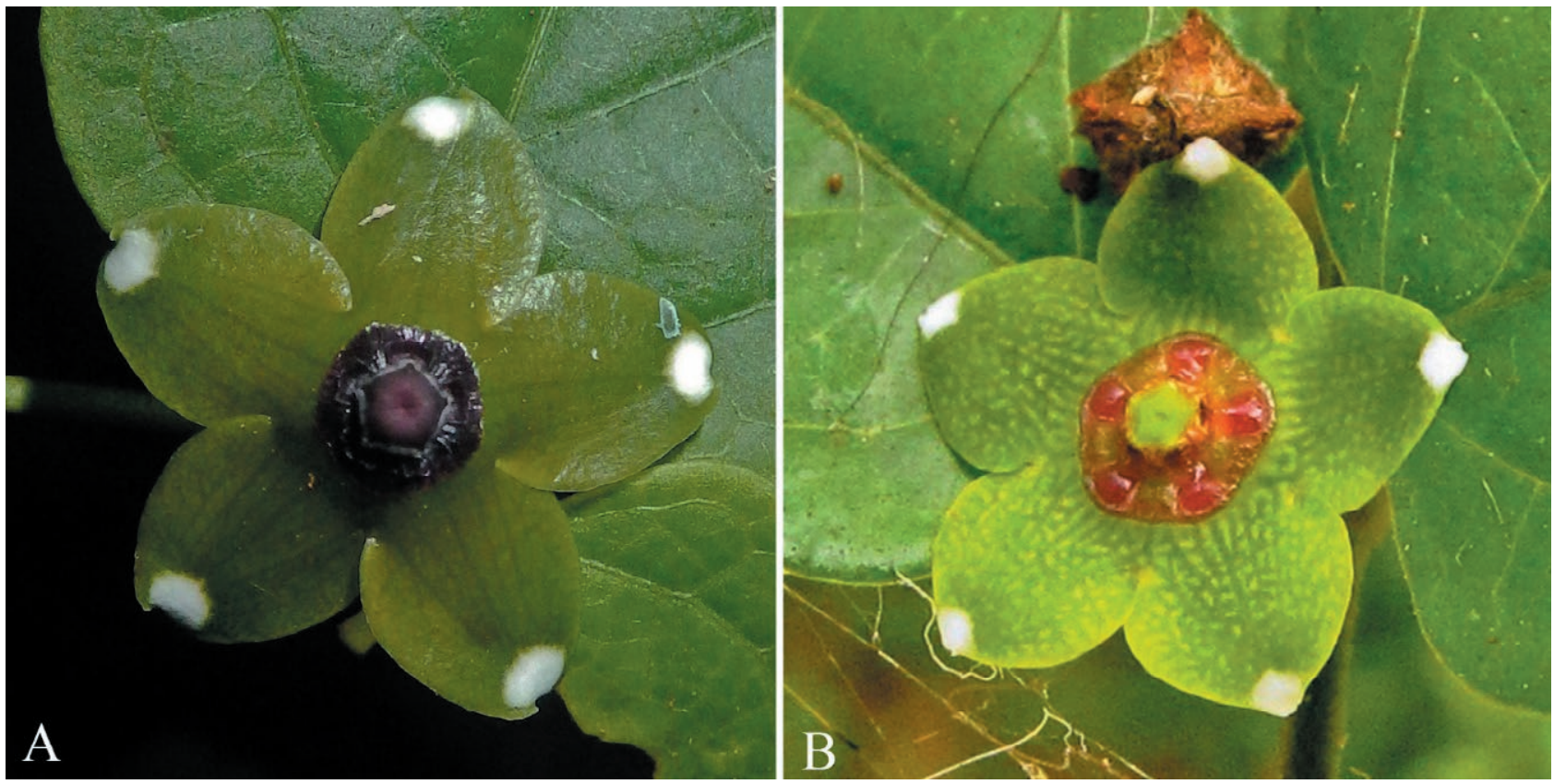

Figure 4. Flowers of Matelea tarrazuana (A) and M. pusilliflora (B) from Yucatan Peninsula. Photo of M. tarrazuana by J.E. Jiménez (Jiménez \& Hidalgo-Mora 5058 [USJ]), and photo of M. pusilliflora by Jan Meerman (Belize), not vouchered.

with the style apex and stigma purple (vs. green) (Figure 4). Diagnostic morphological characteristics to separate these species are given in Table 1.

Three morphological characters are peculiar in this species: the apparent lack of latex, the position of the leaves according to the type of stem and the progressive increase in size in the leaves in the plagiotropic stems. Morales \& Stevens (2020) suggest species of Matelea in Costa Rica has latex, thus Matelea tarrazuana could be the only species of the genus in Costa Rica without latex. Furthermore, there is no documentation of the change in phyllotaxy depending on the type of stem in Matelea nor in the progressive size of the leaves. This species has an opposite-decussate leaves in orthotropic stems and opposite-distichous in plagiotropic stems (branches), and the leaves increasing progressively in size in the branches from the proximal to distal nodes. These three observations could be focused of taxonomic study in future studies of the group because they can represent important characters to differentiate species or clades.

This new species proposed here was found in a remnant forest surrounded by paddocks and especially coffee plantations. Unfortunately, the Zona de los Santos's region has been slowly deforested by coffee plantation in the last decades in less than one year, other three new and narrowly endemic species were published from this area (Cedeño et al. 2020, Juárez \& Morales 2021). Mate- lea tarrazuana is the sixteen species of the genus documented for the country.

\section{Additional specimen examined}

COSTA RICA: San José, Tarrazú, San Lorenzo, San Joaquín, bosque contiguo al río San Joaquín aguas arriba del puente, bosque primario intervenido, $1200-1300 \mathrm{~m}$, $9^{\circ} 34^{\prime} 52.86^{\prime \prime}$ N, 8358'48.90” W, 10 Nov. 2020 (fl.), Jiménez 5483 (USJ, in spirit).

Key to identify the species of Matelea with a reflective white spot in the apex of each corolla lobe for Mesoamerica

1. Corolla and calyx lobes reflexed; tube with a horn between each lobe of the corona M. corniculata

1. Corolla and calyx lobes patent; tube without a horn.............2

2. Corolla lobes longer than wider 3

3. Corolla lobes elliptic and cucullate; staminal corona green to brownish, the center smooth and shiny and the margin opaque, purple and radially striated; stye apex star-like, purple; Chiapas M. emmartinezii

3. Corolla lobes ovate to deltate and flattened; staminal corona with 5 opposite erect wings, yellow to orange; style apex rounded-pentagonal, green; Caribbean lowland rainforest of Nicaragua and Costa Rica M. ocellata 
Table 1. Morphological comparison of the five Mesoamerican species of Matelea that have a reflective white spot in the apex of each corolla lobe.

\begin{tabular}{|c|c|c|c|c|c|}
\hline Structure & M. corniculata & M. emmartinezii & M. ocellata & M. pusilliflora & M. tarrazuana \\
\hline Leaf shape & Ovate to lanceolate & Ovate & Elliptic to ovate & Ovate & Ovate \\
\hline Length $\times$ width $(\mathrm{cm})$ of the leaf blade & $4.5-11 \times 1.5-6.5$ & $4-5.5 \times 1.5-2$ & $3.8-9.2 \times 1.5-3.9$ & $2.9-7 \times 1.1-2.5$ & $2.5-6.5 \times 1.2-3.5$ \\
\hline Number of secondary veins (per side) & $4-5$ & $4-5$ & $3-6$ & $4-6$ & $4-6$ \\
\hline Numbers of colleters in leaves & 2 & $2-4$ & $3-6$ & $2-4$ & $4-6$ \\
\hline Petiole length $(\mathrm{cm})$ & $0.4-1.2$ & $0.5-1$ & $1-2.2$ & $0-3-0.6(-1.8)$ & $0.8-1$ \\
\hline Length $\times$ width $(\mathrm{mm})$ of the sepals & $2.1-3.2 \times 0.8-1.5$ & $2.2 \times 0.9$ & $1.1-1.9 \times 0.7-1.2$ & $2-2.2 \times 1.1-1.2$ & $0.4-0.5 \times 0.1-0.3$ \\
\hline Sepals shape & Ovate, reflexed & Elliptic, patent & Lanceolate, patent & $\begin{array}{l}\text { Lanceolate to } \\
\text { elliptic, patent }\end{array}$ & $\begin{array}{c}\text { Ovate-lanceolate, } \\
\text { patent }\end{array}$ \\
\hline Latex color & Unknown & White & Unknown & Unknown & Colorless \\
\hline Length of pedicel (cm) & $0.3-0.5$ & $0.2-0.25$ & $0.4-1.4$ & $0.1-0.2$ & $0.4-0.6$ \\
\hline Corolla lobes shape & Elliptic-reflexed & $\begin{array}{c}\text { Elliptic-cucullate, } \\
\text { patent }\end{array}$ & Deltate, patent & Ovate, patent & $\begin{array}{l}\text { Ovate to slightly } \\
\text { orbicular, patent }\end{array}$ \\
\hline Corolla color & Brown & Green & Green & Lightgreen & $\begin{array}{c}\text { Green to brownish- } \\
\text { green }\end{array}$ \\
\hline Color of staminal corona & Apparently brown & $\begin{array}{l}\text { Purple greenish to } \\
\text { brownish }\end{array}$ & Yellow to orange & Yellow to orange & Purple \\
\hline $\begin{array}{l}\text { Length } \mathrm{x} \text { width of the corolla lobes } \\
(\mathrm{mm})\end{array}$ & $6.5-9.2 \times 2.5-3.2$ & $4.0 \times 2.7$ & $2.7-3.5 \times 2.1-2.2$ & $2.3-2.7 \times 2.8-3.4$ & $4-5 \times 4-5$ \\
\hline $\begin{array}{l}\text { Length ( } \mathrm{mm}) \text { and (in case) shape of } \\
\text { the corolla tube }\end{array}$ & $\begin{array}{l}0.5, \text { with an erect } \\
\text { horn between each } \\
\text { corolla lobe }\end{array}$ & $1-1.3$ & $0.8-2$ & $1.5-1.7$ & 2 \\
\hline Shape and color of apex style & $\begin{array}{l}\text { Rounded- } \\
\text { pentagonal and } \\
\text { strongly convex, } \\
\text { color unknown }\end{array}$ & Star-like, purple & $\begin{array}{l}\text { Rounded- } \\
\text { pentagonal, } \\
\text { unknown color }\end{array}$ & $\begin{array}{l}\text { Rounded- } \\
\text { pentagonal, green }\end{array}$ & $\begin{array}{l}\text { Rounded- } \\
\text { pentagonal, Purple }\end{array}$ \\
\hline Folicles and seeds & Unknown & Unknown & Unknown & Unknown & Unknown \\
\hline
\end{tabular}

2. Corolla lobes wider than long or as wide as long ... 4

4. Pedicels $0.4-0.6 \mathrm{~cm}$ long, corolla lobes as long as wide, $0.4-$ $0.5 \mathrm{~cm}$ long; staminal corona purple; gynostegium with the style apex and stigma purple; Tarrazú (Costa Rica........

\section{M. tarrazuana}

4. Pedicels $0.1-0.2 \mathrm{~cm}$ long; corolla lobes wider than larger, $0.2-0.3 \mathrm{~cm}$ long; staminal corona orange; gynostegium with the style apex and stigma green; Yucatan Peninsula....

..M. pusilliflora

\section{ACKNOWLEDGMENTS}

We thank Jan Meerman from Belize for the permission to reproduce the photo of $M$. pusilliflora. Barry E. Hammel kindly shared the draft treatment of Matelea from Manual de Plantas de Costa Rica Vol. IV prior to its publication. We thank Maria Fernanda Cordero Pagoaga who made the scientific illustrations using in this work and Marco Cedeño for his support in the map elaboration. We appreciate the constructive and helpful comments of Warren Douglas Stevens and Juan Francisco Morales that improved this manuscript.

\section{REFERENCES}

Cedeño M, Grayum MH, Croat T, Blanco MA. 2020. Three new species of Monstera (Araceae: Monsteroideae: Monstereae) from the Cordillera de Talamanca in Costa Rica, threatened by the expansion of coffee plantations. Nordic Journal of Botany. 38(12): 1-13. Doi: $10.1111 /$ njb.02970

Cortez EB, Lozada-Pérez L, Alvarado-Cárdenas LO. 2018. Two new species of Matelea (Asclepiadoideae: Gonolobeae; Gonolobinae) from México. Systematic Botany. 43(3): 818-825. Doi: 10.1600/036364418X697544

Krings A, Thomas DT, Xiang Q. 2008. On the generic circumscription of Gonolobus (Apocynaceae, Asclepiadoideae): Evidence from molecules and morphology. Systematic Botany. 33: 403-415. Doi: 10.1600/036364408784571527 
Krings A. 2012. Matelea gilbertoana (Apocynaceae), a new species from Venezuela. Systematic Botany. 37: 989-991. Doi: 10.1600/036364412X656473

Holdridge LR. 1967. Life Zone Ecology. Tropical Science Center. San José, Costa Rica. 149 p.

IUCN. 2001. The IUCN Red List categories and criteria, version 3.1. IUCN Species Survival Commission. Gland, Switzerland and Cambridge, U.K. Available from: http://www.iucnredlist.org/technical-documents/categories-and-criteria/2001-categories-criteria (accessed 10 March 2021).

Juárez P, Morales JF. 2021. Pleurothyrium amissum (Lauraceae), A New Endemic Tree from the Talamanca Montane Forest in Costa Rica. Novon. 29: 78-84. Doi: $10.3417 / 2021655$

McDonnell A. 2014. Non-twining milkweed vines of Oklahoma: an overview of Matelea biflora and Matelea cynanchoides (Apocynaceae). Oklahoma Native Plant Record. 14: 67-79. Doi: 10.22488/ okstate.17.100106

Morales JF, Stevens WD. 2020. Apocynaceae. Pp. 330-447. In: Hammel BE, Grayum MH, Herrera C, Zamora N (eds.). Manual de Plantas de Costa Rica. Vol IV, Parte 1: Dicotiledóneas (Acanthaceae-Asteraceae). Monographs Systematic Botany Missouri Botanical Garden. 137: 1-904.

Morillo G. 2015. Contributions to the knowledge of the Gonolobinae (Apocynaceae, Asclepiadoideae) Part III. Pittieria. 39: 191-258.

Spellman DL, Dwyer JD. 1973. A new Matelea from Panama. Annals of Missouri Botanical Garden. 60(2): 568-570. Doi: 10.2307/2395098

Stevens WD. 2009. Asclepiadaceae (s.s.). pp. 703-768. In: Davidse G, Sousa M, Knapp S, Chiang F. (Eds.) Flora Mesoamericana Vol. 4, pt.1. Cucurbitaceae a Polemoniaceae. Universidad Nacional Autónoma de México, Missouri Botanical Garden, The Natural History Museum (London), Ciudad Universitaria, Mexico, D.F.

Steven WD, Arbelaez AL. 2014. A new ocellate species of Matelea (Apocynaceae, Asclepiadoideae) from Mesoamerica. Phytoneuron. 2014-54: 1-3.

Thiers B. 2021. Index Herbariorum: a global directory of public herbaria and associated staff. USA: New York Botanical Garden's Virtual Herbarium. Available at: http://sweetgum.nybg.org/ih/ (accessed 10 March 2021).

Villaseñor JL. 2016. Checklist of the native vascular plants of México. Rev Mex Biodivers. 87: 559-902. Doi: 10.1016/j.rmb.2016.06.017

Woodson RE Jr. 1941. The North American Asclepiadaceae. Annals of the Missouri Botanical Garden. 28: 217-237. Doi: $10.2307 / 2394270$ 